\title{
Risks of Guidelines in Medicine
}

\author{
A.S. Lübbe \\ Department of Palliative Care, Cecilien-Klinik, Bad Lippspringe, Germany
}

\section{Introduction}

Evidence-based medicine (EBM) is the conscientious, explicit, and judicious use of current best evidence in making decisions about the care of individual patients [1]. EBM is also the process of systematically reviewing medical progress and using clinical research findings to add to the delivery of optimum clinical care to patients [2]. Experience, good communication techniques, empathy, intuition, and the ability of the physician to make a decision against what is expected by evidence-based guidelines, however, clearly point out that statistical significance in clinical trials does not always have relevance in the individual case.

If certain quality criteria are met [3], medical decision-making can become more transparent through guidelines. They take into consideration the current knowledge, describe state-ofthe-art diagnosis and treatment, and are typically statements with the aim of supporting physicians in their decision about preferred measures for therapy. Therefore they should contain single components and easy-to-follow strategies [4].

Guidelines are usually based on evidence: In the hierarchy of research designs randomized, controlled trials are considered to be evidence of the highest grade, whereas observations at studies are viewed as having less validity because they reportedly overestimate treatment effects. This, however, has been questioned lately [4].

Evidence-based guidelines should not be applied without taking into consideration the individual patient and the individual circumstances $[5,6]$. Each treatment decision should be made on this basis and with the consent of the informed patient. Standards are never definitive. Guidelines are therefore intended for treatment facilitation in such a way that in each individual case physicians can use a set of procedures that have proven to be successful in the treatment of many patients. $\mathrm{Pa}$ tient autonomy is an ethical and legal prerequisite. Medical guidelines cannot influence patient autonomy, especially in palliative care, they only offer physicians a way to provide the patient with the best information available. The adequate use of guidelines offers major advantages to physicians, other medical staff, and the patient. However, many risks are connected with the unqualified use of guidelines.

\section{Risks in the Application of Guidelines}

\section{Risk 1: Too Many and Heterogeneous Guidelines}

There are many guidelines available (more than 2,500 in Germany at the moment) and it is by no means clear to which clinical situation certain guidelines apply. There are guidelines of different quality with different levels of evidence; and even for one disease, such as a particular cancer, different guidelines exist from different medical societies [7].

\section{Risk 2: Physicians Are Dispensable}

The three main elements to joint clinical decision-making are: disclosure of information about the risks and benefits of therapeutic alternatives, exploration of the patient's evaluation of the therapy and potential outcome, and the actual decision [8]. Again, this is particularly important for older patients with advanced chronic disease, such as cancer.

Ready-to-use guidelines cannot replace the highly experienced, skilful and communicatively able physician. Doctors would be mutually interchangeable and physicians would be little more than skilled medical technocrats, who are responsible more for the diagnosis and less for the treatment.

\section{Risk 3: Evidence-Based Medicine Does Harm to the Elderly, \\ Frail, and Chronically Sick}

Evidence-based medicine is also not kind to the elderly [9]. The 'guideline movement' trusts only the products of randomized controlled trials, or preferably meta analyses of those trials. However, subjects older than 75 years are rarely found in such trials. This population is invisible to scientific medicine. If we teach only what we know and if we know only what we can measure in clinical trials, then the care of the elderly seems to be of little importance. The same often holds true for patients in palliative care. However, we need to recognize that comfort and happiness of the patient are very important and might be

\begin{tabular}{ll}
\hline KARGER & @ 2004 S. Karger GmbH, Freiburg \\
Fax +497614520714 & Accessible online at: \\
$\begin{array}{l}\text { E-mail Information@Karger.de } \\
\text { www.karger.com }\end{array}$ & www.karger.com/onk
\end{tabular}

Andreas S. Lübbe, $\mathrm{MD}, \mathrm{PhD}$

Cecilien-Klinik, Department of Palliative Care MZG Westfalen

Lindenstraße 26, D-33175 Bad Lippspringe Tel. +49 5252 951-203, Fax -254

Email cec-luebbe@medizinisches-zentrum.de 
adversely affected by medical diagnostics and treatment. Therefore, a willingness to make compromises, depending on changing circumstances and an ability to treat without diagnosing are necessary skills of a good physician, even though they do not have a place in evidence-based medicine. All of this will be found rather in the office of the doctor, who is able to consider the complexity.

\section{Risk 4: Guidelines Do Not Work in Complex Clinical Cases}

Deviation from guidelines is often necessary when treating the individual patient. For example, a patient on a palliative care unit with advanced head and neck cancer would on the one hand have a low likelihood of cure with a certain recommended procedure and a statistically estimated survival. On the other hand, palliative treatment may not hold the chance of survival, but a certain time with little side effects and a reasonable quality of life until late in the disease. In this situation a hand-tailored calculation could provide the probabilities of moderate and severe side effects with palliative treatment. [10]. The resultant decision tree established for each patient will tell the physician the best possible solution to a problem, such as the preferred treatment procedure in a malignant disease. Decision analysis offers a repertoire of techniques, which may be useful for the evaluation of complex choices in clinical medicine [11].

The following parameters and treatment aims play a varying role in each clinical case:

- probability of cure from radical treatment,

- survival time for untreated patients,

- life expectancy with palliative treatment,

- life expectancy with radical treatment,

- latency period before complications develop, after curative or palliative treatment

- life expectancy for cured patients, quality factors and survival increments.

Risk 5: Clinical Trials Do Not Represent the Patient Population In addressing the patient's risk of adverse events without treatment and risk of harm with therapy, clinicians must recognize that patients are rarely identical to the average study patient. Differences between study participants and patients in 'real-world practice' tend to be quantitative (differences in degree of risk or response to therapy), rather than qualitative (no risk or adverse response to therapy). Therefore, it is ironic to relate data of a poorly representative sample to the entire affected population $[12,13]$.

\section{Risk 6: Who Decides Which Patient Is Represented by the} Study Aim?

The applicability of clinical trials to individuals depends to a large extent on the outcome parameters used. In the case of cancer trials typical examples of such parameters are: mortality rate, quality of life, or life prolongation. However, what is the best outcome parameter in the individual case and what is its relation to the realistic probabilities with a given treatment? For example, there is little room for regional modification of internationally established standards.

\section{Risk 7: Failure to Adhere to Guidelines or Use of Wrong Guidelines}

Formulation and knowledge of guidelines does not necessarily mean that clinical behavior is being modified. Administrative support and other ways to establish guidelines in everyday clinical practice have been undertaken. Among these efforts are to copy guidelines and to include them into patient's charts and visits. Constant evaluation of and feedback on guideline adherence is therefore a key objective.

In a hypothetical situation, a female patient may be treated for recurrent urinary tract infections (UTI). The family physician judges it an uncomplicated finding. However, over the months, recurrent infections of one kidney lead to unilateral nephrectomy. It comes to a trial and the expert witness decides that it was not an uncomplicated but a complicated UTI, so that the application of guidelines for the treatment of an uncomplicated UTI was wrong and rather guidelines for the treatment of a complicated UTI had to be implemented. The home physician will then be sentenced to payments, because he applied the wrong guidelines.

\section{Risk 8: The Role of the Patient Is Neglected}

The application of statistics drawn from clinical trials to the individual patient is very demanding. But what really makes the experienced physician indispensable is taking into account factors such as the patient's wish and the patient's individual right of self-determination (patient autonomy) to decide in favor of or against a certain treatment.

\section{Risk 9: Guidelines Are not Legally Obligatory}

Guidelines are recommendations, they are not law. The legal implications of guidelines are therefore not clear at this point, at least from an international point of view. It is conceivable, however, and rather likely that published guidelines will be used if liability and insurance questions are raised.

\section{Risk 10: Evidence-Based Medicine Is the Basis for Managed Care}

Managed care structures consider modern management concepts with the objective to directly influence patient and physician behavior. Of course, the instruments of evidencebased medicine as well as guidelines can be used, but they will typically only be utilized if they lead to a control of patient and physician behavior, cost reduction, and the optimization of processes in an economic framework. Thus, managed care does not necessarily aim at the improvement of treatment quality but at cost reduction and therefore cannot be compared with evidence-based medicine [14]. 


\section{Conclusion}

Taken together, the role of the physician is more important than ever, not only to have knowledge of the various guidelines in various diseases, but also to apply those guidelines and to convince the patient of the meaning of those guidelines. In that regard, there is still the need for the freedom of empirical decision making of the individual physician in the individual patient-physician relationship. This will probably remain like this as long as there are patients and doctors.

\section{References}

1 Sackett DL, Rosenberg WM, Gray JA, Haynes RB, Richardson WS: Evidence based medicine: What it is and what it isn't. BMJ 1996;312:71-72.

2 Rosenberg W, Donald A: Evidence-based medicine: An approach to clinical problem solving. BMJ 1995;310:122-1126.

3 AWMF online: www.uni-duesseldorf.de/WWW/ AWMF/awmfleit.htm.

4 Concato J, Shah N, Horwitz RI: Randomized, controlled trials, observational studies, and the hierarchy of research designs. N Engl J Med 2000;342:1887-1892.

5 Kolkmann FW: Qualitätsstandards in der Onkologie aus Sicht der Bundesärztekammer. Forum DKG 1995;10B:71-72.

6 Sackett DL, Richardson WS, Rosenberg W, Haynes RB (Hrsg): Evidenzbasierte Medizin, EBM-Umsetzung und -Vermittlung. Germering, Zuckschwerdt, 1998.

7 Ollenschläger G, Schott G: Leitlinien und Evidenz-basierte Medizin in Deutschland: Aktueller Stand, Erfahrungen der Deutschen Krebsgesllschaft und Ausblick. Onkologe 1999;5:826-829.

8 McAlister F, Straus SE, Guyatt G, Haynes RB for the Evidence-Based Medicine Working Group: Users' guidelines to the medical literature: XX. Integrating research evidence with the care of the individual patient. JAMA 2000;283:28292836.

9 Goodwin JS: Geriatrics and the limits of modern medicine. N Engl J Med 1999:340:1283-1285.

10 Mac Dougall RH, Munro AZ, Wilson JA: Palliation in head and neck cancer; in Doyle D, Hanks G, McDonnell N (eds): The Oxford Textbook of Palliative Medicine (ed 2). Oxford, Oxford University Print, 1998, pp 677-689.

11 Weinstein MC, Fineberg HV, Elstein AS (eds): Clinical Decision Analysis Philadelphia, WB Saunders, 1980.

12 Cottin V, Aroin D, Lasset C: Small-cell lung cancer: Patients included in clinica trials are not representative of the patient population as a whole. Ann Oncol 1999;10:809-815.

13 Straus SE, Sackett DL: Applying evidence to the individual patient. Ann Oncol 1999;10:29-32.

14 Lauterbach K: Vorurteile abbauen. Dtsch Ärztebl 1999;96A:2128-2131.

\section{Impressum}

Die Zeitschrift erscheint zweimonatlich; pro Jahr erscheint 1 Band zu je 6 Heften. Mitglieder der Deutschen Gesellschaft für Hämatologie und Onkologie sowie der Österreichischen Gesellschaft für Hämatologie und Onkologie erhalten die Zeitschrift im Rahmen ihrer Mitgliedschaft. Der Bezug ist im Rahmen des Mitgliedsbeitrags abgegolten. Bezugspreise für Jahrgang 27, 2004: Print-Abonnement EUR 156,-, Online-Abonnement EUR 156,-, Kombi-Abonnement Print/Online EUR 189,-, einschließlich MWSt., zuzüglich Postgebühren. Der Abonnementpreis ist im voraus zahlbar. Das Abonnement der Zeitschrift läuft weiter, wenn es nicht spätestens 4 Wochen vor Abschluss eines Bandes abbestellt wird. Abonnementbestellungen können bei jeder Buchhandlung oder direkt beim Verlag aufgegeben werden:

Deutschland:

S. Karger Verlag für Medizin und

Übrige Länder:

Naturwissenschaften $\mathrm{GmbH}$

S. Karger AG

Allschwilerstr. 10

Lörracher Str. 16a

D-79115 Freiburg

Postfach

CH-4009 Basel

Tel. +49761452070

Fax +497614520714

Tel. +416130611 11

Fax +41613061234

E-mail Information@Karger.de

E-mail Karger@Karger.ch

Anzeigen:

S. Karger Verlag für Medizin und Naturwissenschaften $\mathrm{GmbH}$

Lörracher Str. 16a, D-79115 Freiburg,

Tel. +49761452070

Gültig ist die Preisliste Nr. 14 vom 1. Januar 2004.

Für den Inhalt außerhalb des redaktionellen Teiles (insbesondere Anzeigen, Industrieinformationen, Pressezitate und Kongressinformationen) übernehmen Schriftleitung, Beirat und Verlag keine Gewähr. Eine Markenbezeichnung kann warenzeichenrechtlich geschützt sein, auch wenn bei ihrer Verwendung in dieser Zeitschrift das Zeichen ${ }^{\circledR}$ oder ein anderer Hinweis auf etwa bestehende Schutzrechte fehlen sollte. Für Satzfehler, insbesondere bei Dosierungsangaben, wird keine Gewähr übernommen. Die Zeitschrift sowie alle in ihr enthaltenen einzelnen Beiträge und Abbildungen sind urheberrechtlich geschützt. Jede Verwertung, die nicht ausdrücklich vom Urheberrechtsgesetz zugelassen ist, bedarf der vorherigen Zustimmung des Verlags. Das gilt insbesondere für Vervielfältigungen, Bearbeitungen, Übersetzungen, Mikroverfilmungen und die Einspeicherung und Verarbeitung in elektronischen Systemen.

(C) Copyright 2004 by S. Karger

Verlag für Medizin und Naturwissenschaften $\mathrm{GmbH}$

Lörracher Str. 16a, D-79115 Freiburg

Verlagsleitung und presserechtlich verantwortlich: Sibylle Hopf

Produktionsleitung: Georg Brunner

Anzeigenleitung: Susanne Meister

Gesamtherstellung:

KONKORDIA GmbH, Bühl

Das Medienunternehmen

Bibliographische Dienste
Biological Abstracts
Current Contents/Clinical Medicine
Excerpta Medica/EMBASE
Index Medicus/MEDLINE
Medical Documentation Service
Reference Update
Research Alert
Science Citation Index
SCISEARCH Database

Diese Ausgabe enthält die 6seitige Beilage «Aktuelles rund um Imatinib», hergestellt mit freundlicher Unterstützung durch Novartis Pharma GmbH. 